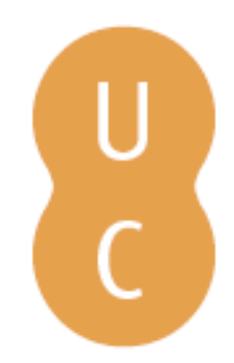

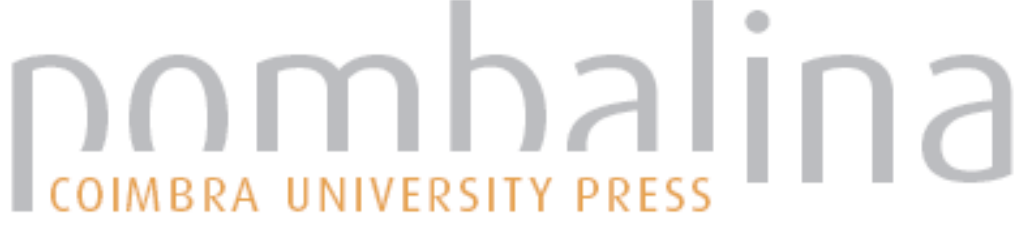

\section{O espírito agónico no Alto Império}
Autor(es):
Pimentel, Maria Cristina
Publicado por: Imprensa da Universidade de Coimbra
URL persistente:
URI:http://hdl.handle.net/10316.2/38372
DOI:
DOI:http://dx.doi.org/10.14195/978-989-26-0371-1_10

Accessed : $\quad$ 26-Apr-2023 14:16:50

A navegação consulta e descarregamento dos títulos inseridos nas Bibliotecas Digitais UC Digitalis, UC Pombalina e UC Impactum, pressupõem a aceitação plena e sem reservas dos Termos e Condições de Uso destas Bibliotecas Digitais, disponíveis em https://digitalis.uc.pt/pt-pt/termos.

Conforme exposto nos referidos Termos e Condições de Uso, o descarregamento de títulos de acesso restrito requer uma licença válida de autorização devendo o utilizador aceder ao(s) documento(s) a partir de um endereço de IP da instituição detentora da supramencionada licença.

Ao utilizador é apenas permitido o descarregamento para uso pessoal, pelo que o emprego do(s) título(s) descarregado(s) para outro fim, designadamente comercial, carece de autorização do respetivo autor ou editor da obra.

Na medida em que todas as obras da UC Digitalis se encontram protegidas pelo Código do Direito de Autor e Direitos Conexos e demais legislação aplicável, toda a cópia, parcial ou total, deste documento, nos casos em que é legalmente admitida, deverá conter ou fazer-se acompanhar por este aviso. 
FRANCISCO DE OLIVEIRA

Coordenação

Ospírito Olímpico

no

novo milénio 
O ESPÍRITO AGÓNICO NO ALTO IMPÉRIO

Maria Crist ina Pimentel Universidade de Lisboa

A acreditar no testemunho dos historiadores, os jogos remontam, em Roma, aos tempos de Rómulo. Com carácter religioso, consistiam basicamente em corridas de carros e tinham lugar no Campo de Marte. Bastará lembrar que foi durante as festas em honra do deus Conso, divindade agrária, que Rómulo e os seus prepararam e executaram o rapto das Sabinas. Terá sido Tarquinio Prisco quem deu uma organização regular aos jogos, estabelecendo que fossem anuais. O mesmo rei mandou ainda vir da Etrúria cavalos especialmente destinados às corridas e, juntando aos primitivos jogos hípicos as primeiras provas de carácter gímnico, fez vir pugiles, também da Etrúria, e instituiu o pugilato, criando a base dos ludi Romani ou magni, celebrados solenemente a partir de então.

Num terceiro momento, chegam a Roma os jogos cénicos, também eles vindos da Etrúria. Esses ludi scaenici, realizados pela primeira vez em 364 a.C. para apaziguar a cólera dos deuses e pôr fim a uma peste devastadora, compreenderam de início apenas danças ou pantomimas, com acompanhamento de flauta. Depois, acrescentaram-se versos e, com Livio Andronico, nos Ludi Romani de 240 a.C., assumiram forma de certame literário. Tais representações dramáticas conquistaram enorme favor e passaram a integrar a maior parte dos jogos realizados em Roma.

Vemos assim presentes, nos jogos romanos, e embora recebidas da Etrúria, as três componentes dos jogos gregos, a que se acrescentaram outras provas e espectáculos específicos, como os combates de gladia- 
dores, as uenationes ou as naumaquias. No capítulo das representações dramáticas, à comédia e à tragédia vieram juntar-se mimos e pantomimas, que tanto aplauso haveriam de colher entre os Romanos.

As provas atléticas, todavia, desde sempre suscitaram uma atitude de desconfiança por parte daqueles Romanos que se distinguiam pela grauitas, desagrado que se traduziu no facto de só muito tarde terem sido incluídas em ludi oferecidos à populaçãoO). Se há notícia de que esse desfavor se foi progressivamente esbatendo entre as classes mais humildes, aquelas que aderiam a todos os espectáculos, sobretudo os menos elaborados intelectualmente, a verdade é que nunca, nem mesmo quando, no séc. I, tais competições eram já prática admitida e frequente, elas deixaram de provocar o desprezo e a crítica da maioria dos senadores e cavaleiros. E essa é a primeira circunstância em que os agones divergem dos jogos gregos e do espírito que os enformava: a perspectiva pela qual eram vistos e avaliados por aqueles cuja opinião tinha peso e influência.

Lembremos o que escreveram três autores, justamente de uma época (séc. I - II d. C.) em que os certamina graeca estavam já aclimatados' em Roma e eram exigidos pelo povo: Séneca, Marcial e Tácito.

O filósofo, que até por razões de saúde não era muito dado a exercícios físicos, revela-se claramente contra o culto do corpo, que prejudica a cultura do espírito, e lança as mais negras suspeições sobre os nefastos efeitos morais da actividade nos ginásios e nos estádios. Por isso, tal como se manifestou contra a crueldade dos jogos na arena do anfiteatro na célebre Epistola 7, também a sua voz se ergue para criticar os que admiram os músculos de uns brutamontes que se treinam para se exibirem, e a essa exibição e a esse treino confinam a vida. Registe-se que tal opinião é sobremaneira significativa se tivermos em conta que, 128 como veremos, é na época de Nero, e por impulso do próprio imperador, que se consagram os jogos atléticos inteiramente segundo a forma grega. Para avaliarmos a perspectiva de Séneca, bastará 1er dois passos

(') Recorde-se o escândalo provocado pela atitude de Cipião Africano, na Sicília, em 204 a. C., onde, além de se vestir e calçar 'à grega', participava nos exercícios do ginásio (Tito Livio XXIX 19, 12). 
significativos das Epistolae ad Lucilium. Na carta 15 (§§ 2-3), o filósofo diz ao amigo:

Cultiva, (...) em primeiro lugar a saúde da alma, e só em segundo lugar a do corpo; esta última, aliás, não te dará grande trabalho se o teu objectivo apenas for gozar de boa saúde. A ginástica destinada a desenvolver a musculatura dos braços, do pescoço, do tórax, é uma insensatez totalmente imprópria dum homem de cultura (...). Pensa também que quanto mais volumoso for o corpo mais entravada e menos ágil se torna a alma! Vários inconvenientes se oferecem a quem se preocupa em excesso com o físico: por um lado o esforço exigido pelos próprios exercícios tira-nos o fôlego e deixa- nos incapazes de atenção e de aplicação a um trabalho intelectual intenso; por outro, o excesso de alimentos limita- nos a inteligência. Como mestres de cultura física recrutamse escravos da pior extracção, homens que dividem o tempo entre o óleo e o vinho - e que consideram bem sucedido o seu dia se transpiraram muito e se em compensação do suor derramado ingeriram bebidas em quantidade equivalente, e tanto mais eficazes se consumidas em jejum!(2)

Na Epistola 80 (§ 2), é ainda mais duro quando escreve:

(...) creio que falei demais quando me gabei de poder gozar de uma tarde de silêncio e um retiro livre de interrupções: agora mesmo me chega aos ouvidos um enorme clamor vindo do estádio, o qual, se me não corta o pensamento, pelo menos o desvia para a consideração do fenómeno desportivo. Ponho- me a pensar na quantidade dos que exercitam o físico, e na escassez dos que ginasticam a inteligência; na afluência que têm os gratuitos espectáculos desportivos, e na ausência de público durante as manifestações culturais; enfim, na debilidade mental desses atletas de quem admiramos as espáduas musculadas.

Também Marcial, embora fosse um dos poetas que apoiavam sem reservas a política do princeps no poder, Domiciano, o fundador do agon Capitolinus totalmente concebido segundo o paradigma olímpico, não conseguiu esconder o seu desacordo, para não dizer desprezo, relativamente aos que se entregavam ao exercício físico ou se treinavam em provas atléticas. Sirva de exemplo o epigrama VII 32, em que louva um seu amigo, Ático(3), justamente porque cultiva o espírito e não o corpo,

(2) A tradução dos passos das epístolas é de José António Segurado e Campos (Lúcio Aneu Séneca, Cartas a Lucilio. Lisboa, Fundação Calouste Gulbenkian, 1991).

(3) Com base no $I^{\circ}$ dístico deste epigrama (Attice, facundae renouas qui nomina gentis / nec sinis ingentem conticuisse domum), há quem julgue tratar-se este Atico de descendente de Tito Pomponio Atico. 
porque, em sua casa, há lugar para a filosofia mas não para o massagista e o mestre de pugilato. Para estes, reserva o epigramatista traços que quase parecem caricaturais, mas são bem reveladores do desprezo que Ihes vota: se a este aponta a fracta auris (cf. v.5), àquele, o sordidus unctor, censura-o porque rapit immeritas ... opes (v.6). Não estamos afinal muito longe da crítica bem-humorada, mas nem por isso menos certeira, de Lucilio, o epigramatista de língua grega da época de Nero e modelo de Marcial, que, em epigramas como XI 77 e 79 da Antologia Palatina, nos fala respectivamente de um Estratofonte que, depois de quatro horas de pugilato, nem se reconhecia a si mesmo no espelho, e de um Cleômbroto(4), vencedor do pugilato nos jogos olímpicos, mas que, em casa, apanhava tareia da mulher.

Paradigmática é, todavia, a reflexão de Tácito em Annales XIV 20. Nesse passo, o historiador enumera os argumentos de todos aqueles que reagiram negativamente à criação de jogos gregos por Nero, em 60: nessa exibição gratuita de exercícios físicos, sem qualquer objectivo a não ser o culto do corpo e o deleite da assistência, nos corpos nus que se exibiam, os Romanos de mais puros e exigentes costumes viam um caminho fácil para a degradação moral, um incentivo à ociosidade e, consequentemente, uma porta aberta à decadência. Tácito lembra que tal perspectiva era aproximadamente a mesma que impediu durante mais de dois séculos a construção de um teatro totalmente em pedra, que só Pompeio conseguiu pôr de pé, e ainda assim cautelosamente integrado num complexo arquitectónico de cariz religioso(5). Também nesse caso as vozes discordantes denunciavam o perigo da inacção, proporcionada e incentivada pela possibilidade de se ficar sentado, durante todo o dia, a assistir a peças teatrais. Não deverá também esquecer-se que os Romanos apontavam como uma das causas para a decadência dos Gregos e para a sua submissão ao jugo de Roma justamente a degradação dos costumes, patenteada nos recintos dos jogos por intervenientes e assistentes, aqueles exibindo-se e exercitando-se sem ter em vista a guerra, a defesa e a autonomia da pátria, estes assistindo inactivos, cada vez mais *10

(4) Não passe despercebida a ironia da etimologia do nome.

(5) Sobre a 'associação' do teatro ao templo a Venus Victrix, v.Tertuliano, De spectaculis 10, 3- 6. 
indolentes e corrompidos. Recorde-se ainda que já Cícero considerava que a origem e a frequência das relações homossexuais entre os Gregos se devia à permissividade que reinava nos ginásios( $(6)$.

A verdade é que, e retomamos o passo de Tácito, os partidários da aceitação dos certamina graeca em Roma, em particular dos Neronia, argumentavam que, encarregando-se o Estado da realização e financiamento desses jogos, se impediria que o povo pedisse e conseguisse os agones de particulares com mais ou menos escrúpulos, que os dariam com intenções sem dúvida fruto da ambição política. Porque o povo já então os exigia, completamente conquistado, afinal, pelos músculos dos atletas profissionais. A perspectiva de Tácito, porém, fica explícita quando, a abrir o $\S 21$, em que apresenta as razões dos que defendiam os agones gregos, embora reconheça que eles eram mais numerosos que os seus detractores, diz: Pluribus ipsa licentia placebat, ac tamen honesta nomina praetendebant.

Importa, assim, acompanhar o longo percurso que vai desde a primeira realização dos agones gregos, no séc. II a.C, até à sua plena implantação, no séc. I d.C., com o estatuto de espectáculo reclamado pelo povo, bem como ver quem foram os políticos e principes responsáveis pelo desenvolvimento desses certames, e avaliar as razões e objectivos que os terão movido.

Durante a República, os óyẃvßï ou certamina graeca realizaram-se poucas vezes, sempre em ocasiões especiais e apenas nos dois últimos séculos. O primeiro que ofereceu ao povo esse tipo de jogos, para os quais chamou muitos atletas gregos, foi Marco Fúlvio Nobilior, em 186 a.C., justamente no ano em que foram introduzidas em Roma, pelo mesmo Nobilior, as uenationesi7). Seguiu-se-Ihe Sula, em 80 a.C., por ocasião da celebração do triunfo sobre Mitridates. Os atletas que fez vir para os inúmeros torneios, em Roma, foram tantos que, nesse ano, em que devia celebrar-se a $175^{a}$ Olimpíada, houve necessidade de a suspender, pois não havia participantes em número suficiente, excepto para a prova da corrida de um estádio( 8 ). Em seguida, coube ao edil Marco

${ }^{(6)}$ Cf Tuse IV 70. V.tb. Plutarco, Quaest. Rom. 40.

(7) Tito Livio XXXIX 22, 2. Nobilior celebrava o seu triunfo sobre os Etólios.

(8)Apiano, Bellum ciuile I 99, 463- 464. 
Pompeio, por ocasião da inauguração do teatro com o seu nome, em 55 a.C.(10), Gaio Escribónio Curião, nas exéquias de seu pai, em 53 a.C.(M), e, por fim, em 46 a.C., Júlio César(12>. Nestes últimos jogos, as provas atléticas prolongaram-se por três dias consecutivos, num estádio em madeira construído para o efeito no Campo de Marte, e que se desmontou, terminadas as festas.

Com a instauração do principado, os jogos, na sua generalidade, tornaram-se cada vez mais numerosos. Augusto não deixou de aproveitar esta forma de consolidar o seu poder junto do povo, tanto mais que ele próprio era apreciador de espectáculos e fazia questão, em gesto que lhe garantia a popularidade e Ihe satisfazia os gostos pessoais, de assistir aos jogos acompanhado da mulher e da descendência< ${ }^{13}$ ).

No capítulo específico dos chamados certamina graeca, o próprio Augusto regista nas Res gestae( $(14)$ : Bis athletarum undique accitorum spectaculum populo praebui meo nomine et tertium nepotis mei nomine. Suetonio acrescenta que athletis et conseruauit priuilegia et $\quad 15\rangle$, medidas acompanhadas da exigência de uma severa disciplina nas certationes dos ginásios e da exclusão rigorosa das mulheres da assistência aos espectáculos com atletasí16). O mesmo historiador informa-nos ainda sobre um gosto particular de Augusto pelo pugilato, que o levava a apreciar tal luta não só entre profissionais mas até entre os que brigavam, temere ac sine arte, em qualquer canto ou rua(17).

No entanto, em medida táctica e cuidadosamente calculada, evitou a realização regular de certamina graeca na capital. Em vez disso, aproveitou os jogos em honra de Apoio que já se realizavam, de dois em dois anos, em Accio e, em celebração da sua vitória sobre Marco António e Cleópatra, renovou- os com o maior esplendor. Esses 'Átı $\alpha$ passaram

(12) Suet., Caes. 39, 3.

(13) Suet., Aug. 45, I.

(14) § 22, I. Cf. Suet., Aug. 43, 2; 45, 4.

O5) Aug. 45, 6.

(16) Aug. 44, 5.

(17) Suet., Aug. 45, 5. 
a celebrar-se em Nicopolis, a cidade que Augusto fundou perto de Áccio para recordar o seu triunfo. Tinham lugar de quatro em quatro anos, talvez em 2 de Setembro, a data da batalha, e, no mundo grego, passaram a contar-se como os quintos jogos, logo após os Olímpicos, os Píticos, os Nemeus e os Istmicos. Foram os primeiros jogos gregos, instituídos pela autoridade romana, a ter realização periódica estabelecida. Compreendiam corridas de cavalos e provas musicais e gímnicasO8). Nestas, segundo o uso grego, os atletas dividiam-se em categorias, con-

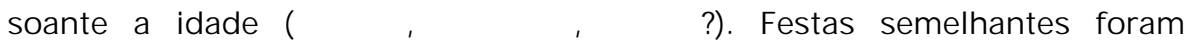
decretadas pelo Senado, em Roma, mas com carácter excepcional, em honra do princeps e da sua vitóriaO9). Parece ter sido durante a celebração destes Actia de Roma, em 29 a.C., que, pela primeira vez, membros da nobilitas conduziram carros nas corridas do Circo. Os Actia de Nicópolis realizaram-se até ao fim do paganismo e Juliano restabeleceu- os durante o seu breve império.

Num segundo momento, em 2 d.C., Augusto instituiu os Augustali em Nápoles, cidade onde, pela origem da maioria da população, os jogos gregos também seriam mais bem recebidos do que em Roma. Celebravam o princeps, num quinquennale certamen gymnicum em que, além das provas usuais, havia um concurso de poesia grega. Designados

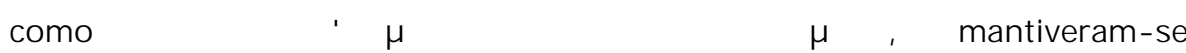
mesmo depois da morte de Augusto( ${ }^{\circ}$ ). Sabemos por Suetónioí* 2021 ) que Cláudio fez representar, em sessão destes jogos realizada durante o seu principado, uma comédia grega de seu irmão Germânico, que obteve o prémio. Será ainda curioso lembrar, como testemunho do apreço que Augusto tinha pelos certamina graeca, que, velho, doente e poucos dias antes de morrer, o princeps se deslocou à Campania e, em Nápoles, assistiu do princípio ao fim aos Sebastá(22)

Depois de Augusto, porque os jogos atléticos se haviam tornado mais populares e solicitados, outros imperadores os proporcionaram,

(18) Suet., Aug. 18, 3; Díon 51. 1.2.

(19) Díon 53. 1.5.

(20) Estrabão V 4, 7.

(2i )Claud. 11,5.

(22) Suet., Aug. 98, 9: Veleio Patérculo II 123, I. Augusto morreu em Nola, poucos dias depois (19 de Agosto de 14). 
nomeadamente Caligula, em 38-39, que os deu, em vários lugares do império, celebrando o dies natalis de sua irmã muito amada e recémdesaparecida, Drusila(23). Também Cláudio, em 44, para festejar o triunfo britânico, fez exibir no Circo, alternadamente, lutas de atletas, corridas de cavalos e uenationesi24).

Foi, porém, Nero quem primeiro instituiu, na capital, uns jogos inteiramente segundo os moldes gregos e pagos pelo fisco: os Neronia, celebrados pela primeira vez no ano 60. Tal certame, porém, mais não é do que uma etapa na progressiva e bem esquematizada conquista da intenção de Nero se apresentar aos Romanos, seus súbditos, como artista, mais do que como governante $\left({ }^{25}\right)$. Recordemos, pois, os diferentes passos que prepararam esse momento culminante do seu principado.

Desde muito cedo, Nero manifestou vontade de se exibir como artista, que queria ser sem entraves nem censuras(26). A princípio, Séneca e Afrânio Burro, seus preceptores e, depois, seus conselheiros, pensaram ser possível travar-lhe os ímpetos, deixando que se exibisse em privado. Para isso, preparou-se um recinto onde Nero pudesse, longe do olhar público, entregar-se ao prazer das corridas(27). Em breve, porém, foram surgindo convidados, povo, e este de imediato se identificou com um princeps que tinha os mesmos gostos que o comum dos mortais e com eles vibrava. Como nota Tácito (Ann. XIV 14, 3), tal sucesso fez com que essas exibições semi-privadas, em vez de provocarem satietatem, servissem afinal a Nero de incitamentum. Bem depressa o princeps fez com que membros das classes mais dignas descessem à arena, corressem no circo, subissem à cena. As interpretações antigas não variam muito sobre a intenção que o moveu: arrastar

(23) Díon 59. 13. 8.

(24) Díon 60. 23. 5.

(25) Cf. G. Charles- Picard, Auguste et Néron. Le secret de I' Empire. Paris, Hachette, 1962, p. I 38: "Néron est (...) le seul monarque qui se soit considéré exclusivement comme un artiste; (...) Mais Néron voulait être un artiste professionnel, et ce métier passait pour lui avant même celui d'empereur."

(26) Era ainda uma criança quando, constantissime fauorabiliterque, participou no ludus Troiae, durante um espectáculo circense (Suet., Nero 7, I).

(27) Tratou- se do estádio aberto por Caligula, no Vaticano, que se preparou para o efeito. 
outros consigo, no opróbrio, mascarando assim a sua própria infâmia. Mas as razões podem ter sido múltiplas: constrangimento para uns, adulação para outros, mas talvez também, para muitos, sincero empenho e adesão a um programa ideológico e artístico, o do princepsi28).

Em 59, como diz Tácito, ne tamen adhuc publico theatro dehonestaretur (Ann. XIV 15, I), Nero instituiu e realizou, nos seus jardins privados, os ludi luuenales, jogos de tipo tradicional, classificados pelo mesmo historiador como certamina uitiorum ( $\S 3$ ). Para neles participarem, inscreveram-se muitos Romanos, homens e mulheres, jovens e velhos, de maior ou menor nobreza, num crescendo de flagitium e de infamia que culminou com a exibição de Nero, tocando cítara e modulando a voz(29). A aplaudi-lo tinha o recém-criado corpo de Augustiani, a claque de filhos de cavaleiros e jovens plebeus, escolhidos entre os mais robustos, num total de cerca de 5 mil membros, que davam apoio permanente às exibições artísticas do princeps. Recorde-se que, divididos em facções, a cada uma competia um diferente modo de aplaudir $\left(3^{\circ}\right)$. Todos os jovens usavam o cabelo comprido e vestes sumptuosas. Os chefes da claque recebiam a quantia de 400 mil sestércios, soma que, note- se, era a exigível no censo para se ser eques.

Em 60, diz Suetónio (Nero 12, 7), instituit et quinquennale certamen primus omnium Romae more Graeco triplex, musicum gymnicum equestre, quod appellauit Neronia(3) Em claro gesto de 'convite' às classes dominantes, senatui quoque et equiti oleum praebuiti32). Além disso, e para mais honrar o agon, fê- lo presidir por consulares, tirados à sorte, e não, como era norma, por pretores. Para que assistissem às provas atléticas, e contra tudo o que era aceitável, convidou as Vestais, sob pretexto de que, em Olímpia, também as sacerdotisas de Deméter o faziam. Os

(28) Cf. E. Cizek, Néron. Paris, Fayard, 1982, p. 163: "Le code culturel que Néron voulut imposer reposait sur deux maîtres mots, l'un grec, l'autre latin: agôn et luxus. Ces deux termes définissent les métavaleurs qui, dans l'esprit de l'empereur et de ses partisans, devaient remplacer la pietas et la fides."

${ }^{(29)}$ Sobre os luuenalia, v.tb. Dion 62. 19- 20.

(39) Suet., Nero 20, 5: bombos et imbrices et testas uocabant.

(3) Cf. Tácito, Ann. XIV 20, I: quinquennale ludricum Romae institutum est ad morem Graeci certaminis. Sobre os Neronia, v.tb. Dion 62. 21.

(32) Cf Tácito, Ann. XIV 47, 2, que ironicamente atribui essa 'prodigalidade à moda grega' ao momento em que, em 60, dedicou um ginásio, no Campo de Marte. 
espectáculos prolongavam-se pela noite e, em Roma, muitos foram os que envergaram trajes gregos, prática que Tácito(33) se apressa a registar logo ter passado de moda, assim que terminaram os jogos. O único aspecto em que os Neronia se distinguiam dos grandes jogos gregos era na periodicidade da sua realização, pois tinham lugar de cinco em cinco anos.

Em 60, Nero não participou nas provas, mas aceitou a coroa de eloquência e de poesia latinas, que os juízes lhe concederam por unanimidade. Quanto ao prémio de tocador de lira, que também lhe atribuíram, mandou, depois de se ajoelhar, que a colocassem, em oferenda, na estátua de Augusto( $\left.{ }^{34}\right)$.

Entre os outros participantes, contava-se Lucano, que ganhou uma coroa no concurso de poesia com uma composição de elogio ao imperador, de quem era ainda, na altura, apoiante indefectíveK ${ }^{35}$ ).

Nero, porém, bem depressa considerou que o seu talento se perdia sem uma condigna divulgação. Cada dia era mais forte o seu desejo de cantar em público, de representar. Não ousando, todavia, apresentar-se em Roma, escolheu Nápoles, quasi Graeca urbs (Tácito, Ann. XV 33, 2), considerando desde logo que aí faria uma espécie de ensaio geral para a exibição na capital e, em seguida, na Grécia, única região onde, segundo dizia, Ihe apreciariam devidamente o talento( ${ }^{36}$ ).

Nesse ano de 64, em Nápoles, nem um tremor de terra(37) impediu que Nero terminasse a sua prova. Cantou por diversas vezes, dias a fio, aplaudido por todos e, em primeiro lugar, pelos Augustiani que o acompanhavam. Mas nem isso lhe bastou, porque não era em Roma, nem na Grécia. Toma, então, decisões e age de forma coerente com o desejo manifesto de se identificar com Apoio e ser reconhecido como o maior artista.

(33) Ann. XIV 21,4.

(34) Cf. G. Charles- Picard, op. cit, p.22I: "par cet hommage il entendait marquer que son talent, loin de le faire déroger, consacrait en lui le digne héritier du fondateur de la dynastie."

(35) Suet., Vita Lucani $1,1$.

(36) Cf. Tácito, Ann. XV 33, 2.

(37) Tácito (Ann. XV 34, I) fala de um outro acidente: após a saída de todos os espectadores de uma sessão, o teatro ruiu, o que para muitos foi presságio do desagrado dos deuses. Mas Nero interpretou o facto de outro modo, de imediato compondo hinos de acção de graças aos deuses pelo facto miraculoso de não ter morrido ninguém. 
Aproximando-se o momento da segunda realização dos Neronia, o Senado, ut dedecus auerteret (Tácito, Ann. XVI 4, I), ofereceu a Nero, de imediato e por antecipação, a vitória na prova de canto e também a coroa de eloquência. Mas ele rejeitou essa infracção às regras, repreendeu o Senado e declarou a sua intenção de participar em pé de igualdade com os outros concorrentes, submetendo-se em tudo ao regulamento e à decisão dos juízes. Suetónio afirma que Nero fez antecipar alguns meses a realização dessa segunda sessão dos Neronia, impaciente como estava por se apresentar perante o povo da sua capital e também, uma vez que acabara de esmagar a conjura de Pisão, de se mostrar em toda a sua glória de imperador-artista. Assim, inscreveu- se regularmente como citaredo e actor, entoou uma Níobe, de sua autoria, que só cessou pelo fim da tarde, e decidiu suspender essa prova e a atribuição do prémio, que adiou para o ano seguinte, ut saepius canendi occasio esset (Suet., Nero 21, 2). Representou ainda vários papéis em diversas tragédias. Suetónio regista as preferências de Nero quanto aos papéis trágicos: Cânace em trabalho de parto, Orestes matricida, Edipo cego, Hércules enlouquecido(38). Tácito acrescenta pormenores sobre o respeito manifestado por Nero relativamente às regras do certame: não se sentou, mesmo em caso de cansaço, limpou o suor apenas com a veste que envergava, cuidou de que não fossem visíveis nulla oris aut narium excrementa(39) (Ann. XV 4, 3).

Entre os espectadores havia delegações vindas de todo o império. Parte desses enviados assistiam ao agon mais ou menos constrangidos e, no dizer de Tácito( ${ }^{4}$ ), quase todos se sentiram relutantes em aceitar e suportar tanta indignidade. Mas, vigilantes, havia soldados que, à bastonada, os obrigavam a todos a aplaudir entusiasticamente. Entre a assistência espalhavam- se ainda espiões, que observavam as reacções de todos e registavam o apoio manifestado ou o enfado traído pelo rosto ou pelo sono $\left({ }^{41}\right)$.

(38) Nero 21,6. V.tb. Díon 62. 9. 4.

(39) Ann. XV 4, 3. Suetónio regista semelhantes preocupações, mas relativamente à participação nos jogos da Grécia (Nero 24, I).

(40)Ann. XVI 5, I.

(4) Um dos que teve problemas por se deixar adormecer foi o futuro imperador Vespasiano (Ann. XVI 5, 3). Suetónio (Vesp. 4, 8), porém, refere tal atitude de desinteresse, que o levava a adormecer ou a não ir sequer aos espectáculos de Nero, como tendo tido 
Por fim, em fins de Setembro de 66, Nero empreende a viagem à Grécia, há muito desejada e já adiada algumas vezes. As cidades gregas haviam-Ihe enviado pouco antes todas as coroas dos concursos de citaredos. Mais se firmou no princeps a opinião de que só os Gregos eram realmente capazes de avaliar o seu talento de poeta, actor, citaredo, auriga. Moviam-no ainda outros projectos, como dar início à abertura do istmo de Corinto.

Na Grécia, para poder participar em todos os jogos sagrados, fê-los concentrar num só ano, adiantando a data de realização dos Olímpicos e dos Nemeus. Em Olímpia, e ao contrário do uso, introduziu as competições musicais, para que pudesse vencê-las. Fazia-se acompanhar de uma enorme comitiva de senadores, escritores, artistas, Augustiani, e dos nerone/o/, os apoiantes organizados como um exército que, em vez de armas, transportavam instrumentos musicais e usavam vestes de actores em vez de equipamento militari ${ }^{42}$ ). Comportou-se como qualquer outro concorrente, inscreveu-se, respeitando, pelo menos na aparência, as regras, preocupava-se com os resultados. Suetónio conta, no entanto, que ele se deixava tomar pela aemulatio de adversários e pelo metus relativamente aos juízes. Assim, àqueles observava- os, serviase de expedientes pouco limpos, denegria-lhes a fama, ou tentava mesmo suborná-los, se os sentia superiores a si. Aos juízes, tentava captá-los com palavras doces de aceitação prévia das suas decisões e com a manifestação da sua pretensa humildade.

Participou nas corridas de carrosi43), exibiu-se como citaredo, prometeu mesmo apresentar-se como atleta. Aguardava, sentindo ou simulando inquietação e ansiedade, o veredicto do júri, que obviamente Ihe foi sempre favorável. Ele próprio se proclamava vencedor e, para apagar de vez a memória de todos os anteriores vencedores dos jogos, mandou abater e destruir todas as estátuas e imagens que os 138 representavam( $\left.{ }^{44}\right)$.

lugar durante a viagem de Nero à Grécia. Vespasiano faria parte da comitiva do princeps e, por tais actos, teria caído em desgraça.

(«> Díon 62. 8. 3- 4.

(43) Em Olímpia, com um carro puxado por dez cavalos (Suet., Nero 24, 4).

(44) Suet., Nero 24, 3. 
Ninguém podia abandonar o local dos espectáculos enquanto ele se exibia. Conta-se que houve mulheres que deram à luz no local, que muitos se fingiram de mortos para serem levados do recinto sem incorrerem em nenhuma penalização.

Como se espera, conquistou coroas atrás de coroas, aplausos retumbantes, talvez sinceros por parte de muitos. Os juízes não lhe negaram os prémios, mesmo quando as provas não correram bem. Numa corrida, o carro virou-se, lançando o imperador por terra. Mesmo assim, foi vencedor(45). Sagrou-se $\pi \varepsilon \rho$ เобovíkns, vencedor nos quatro jogos.

Em Corinto, em Novembro de 67, durante os jogos Istmicos, no mesmo estádio onde, em 196 a. C, Tito Quíncio Flaminino tinha proclamado a liberdade da Grécia, Nero anunciou solenemente a restauração dessa liberdade e a imunidade fiscal para a Acaia. Na prática, tal medida traduzia-se em retirar a província da alçada do Senado(46). Mas, de forma simbólica, Nero mais não fazia que recompensar aqueles que tão completa e rendidamente lhe reconheciam o génio. Nesse sentido, concedeu a cidadania romana a vários dignitários das cidades gregas, bem como aos juízes que the avaliaram as provas(47). Fosse apenas por isso, fosse também porque deveras o apreciaram, a verdade é que Nero conquistou grande apoio entre os Gregos(48).

Em Roma deixara um seu liberto, Hélio, encarregado da governação. Como este lhe pedisse que regressasse, respondeu- Ihe que o deveria aconselhar antes a que voltasse digno de Nero(49). Só as notícias alarmantes que Ihe chegaram de Roma, sobre os focos de revolta que ameaçavam o poder, o fizeram renunciar a prolongar a sua presença na Grécia e até a continuar pelo Oriente.

(45) Suet., Nero 24, 4

(46) A medida veio a ser revogada por Vespasiano, que fez da Acaia, de novo, uma província senatorial e pôs fim à imunidade (Suet., Vesp. 8. 6).

(47) Suet., Nero 24, 5; Díon 62. 14. I.

(48) Não visitou, porém, Esparta, talvez porque os valores aí cultivados eram semelhantes aos da aristocracia renitente e conservadora de Roma, nem Atenas, símbolo da democracia. Parece que também evitou Eleusis, de cujos ritos estavam excluídos os criminosos. Cf. Suet., Nero 34, 8; Díon 62. 14. 2- 3.

(49) Suet., Nero 23, 2 (suadere et optare potius debes, ut Nerone dignus reuertar); cf. Dion 62. 19. I, que diz que Hélio, não conseguindo o regresso de Nero, foi ele próprio à Grécia para o informar da preparação de uma conjura. Só assim o princeps se decidiu a voltar. 
Regressou como os triunfadores dos jogos gregos. Entrou em Nápoles, num carro puxado por cavalos brancos, por uma fenda que fez abrir na muralha. Depois dirigiu-se a Ancio, sua terra natal, em seguida à sua propriedade de Alba.

Entrou em Roma em Março de 68, em autêntico triunfo(50). No carro em que Augusto celebrara o triunfo, dirigiu-se ao templo de Apoio, no Palatino, e só depois ao de Júpiter, no Capitólioís1). Envergava um manto púrpura recamado de estrelas de ouro, na cabeça trazia a coroa olímpica, na mão direita a coroa pítica. Acompanhava-o um longo cortejo em que se ostentavam painéis contendo a indicação de cada vitória obtida nos jogos, local e rivais vencidos. Exibem-se também as 1808 coroas que conquistou. A sua volta, os Augustiani proclamam- se seus soldados, o povo aclama- o como Hércules, como Apoio.

Menos de três meses depois, Nero morreu, abandonado por todos, perseguido por todos, hesitando no gesto que o pouparia ao cruel castigo para que o procuravam. Ainda assim, pouco antes de morrer, ter- se- á lamentado: Qualis artifex pereoU52).

Dos certamina instituídos por Nero, nenhum teve continuação após a sua morte. Em 240, porém, Gordiano, antes de partir em campanha contra os Persas, restaurou magnificamente o agon Neroneus, sob o nome de agon Mineruae (Aur. Vict. De Caes. 27. 7).

Como todos os principes, uns levados mais pela leuitas, a característica que consistia em dizerem e fazerem o que o povo deles esperava para conquistarem a aura popularis, outros sobretudo pela necessidade, que sentiam premente, de trazer o povo satisfeito e entretido, Domiciano não deixou de dar jogos e de a eles assistirí53). Suetónio (Dom. 4, I) assegura: Spectacula assidue magnifica et sumptuosa edidit non in amphitheatro modo, uerum et in circo, ubi praeter sollemnes bigarum quadrigarumque cursus proelium etiam duplex, equestre ac pedestre, 140 commisit; at in amphitheatro nauale quoque.

(59) Leia- se a descrição em Suet. Nero 25 e Dion 62. 20, bem como a interpretação do ritual criado, em G. Charles- Picard, op. cil p 230- 1.

(5) Suet., Nero 25; Dion 62. 20.

i") Suet., Nero 49, I.

(53) Presença documentada em Marcial IV 2; VI 34 e VIII I I, com inevitável alusão ao apoio entusiástico que a multidão manifesta ao seu chefe. V.tb. Suet., Dom. I 3, 2- 3. 
E é justamente com Domiciano que encontramos a realização de outros jogos plena e totalmente decalcados dos gregos, quer na sua estrutura, quer inclusive na sua forma e aparato exteriores. Trata-se dos ludi Capitolini, instituídos em 86 d.C.(54) em honra de Júpiter, que se realizavam de quatro em quatro anos, no princípio do Verão. O modelo é o dos jogos Olímpicos, de tal forma que este agon Capitolinus aparece

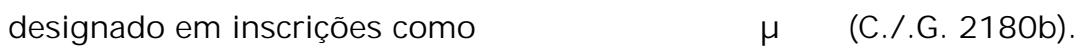

Em primeiro lugar, poderemos interrogar-nos: em honra de Júpiter porquê? As respostas parecem ser várias e a mais simples de todas é, sem dúvida, a do paralelo com os jogos Olímpicos, dedicados a Zeus. No caso de Domiciano, as razões são mais complexas e prendem-se com a sua ideologia política e a própria propaganda que dela fazia.

Com efeito, desde sempre Domiciano se apresentou como especial devoto de duas divindades: Júpiter e Minerva. A esta última (quam superstitiose colebat, diz Suetonio, Dom. 15, 7) dedicou também uns jogos, os ludi Albani, que fazia realizar anualmente na sua uilla de Alba, durante as Quinquátrias (19 a 23 de Março). Aí se davam eximias uenationes et scaenicos ludos superque oratorum ac poetarum certamina (Suet. Dom. 4, I I). O prémio para os vencedores era uma coroa de folhas de oliveira, em ouro.

A ligação com Júpiter apresentava-a o princeps como muito íntima e especial, fazendo remontar a protecção que o senhor dos deuses the dispensava ao momento em que os partidários de Vitélio, em 19 de Dezembro de 69, tomaram de assalto o Capitólio, onde o jovem Domiciano, seu tio Flávio Sabino e uns quantos partidários de seu pai, Vespasiano, se encontravam refugiados. Quando os Vitelianos lançaram fogo ao templo de Júpiter, Domiciano escondeu-se na casa do aedituus, o guardião do templo(55). De manhã, terá escapado milagrosamente: disfarçado de sacerdote de Isis e misturado com devotos de outros cultos, fugiu da colina e buscou refúgio seguro até que a vitória de seu pai se confirmasse (Suet. Dom. resultado mais da cobardia que I, 4), atitude que Tácito insinua ter da cautela. O tio, ao invés, foi

(54)Censorino, De die natali 18. 159.

(55) Tácito, H/st. III 74, I; Suet., Dom. I, 4. Díon Cássio (64. 17. 4) apresenta uma versão ligeiramente diferente: Domiciano ter-se-ia escapado do Capitólio na confusão inicial dos recontros entre as tropas. 
cruelmente assassinado. Domiciano soube aproveitar o acontecimento para divulgar a versão de que Júpiter o protegera especialmente. Logo que seu pai tomou o poder, fez construir um sacellum, um pequeno santuário a luppiter Conseruator, no local onde se escondera e, quando ascendeu ao poder, em 81, nesse mesmo local ergueu um templo magnífico a luppiter Custos, além de ter procedido à restauração, em moldes grandiosos(56), do templo de luppiter Optimus Maximus que existia na colina, e que ardera de novo, em 80, após a reconstrução levada a cabo por Vespasiano(57). Com base numa referência de Marcial $(V$ 5, 7: Capitolini caelestia carmina belli), pensa-se que um poema épico que Domiciano compôs, na juventude(58), se ocupava desses terríveis combates pela posse do Capitólio. Também aí evocava, com certeza, essa atenção protectora de que fora alvo por parte de Júpiter e exporia a tese, que sempre divulgou, de que fora ele a conseguir a vitória e a garantir ao pai, Vespasiano, e, mais tarde, ao irmão, Tito, o poder de que generosamente abdicara mas que por legítimo direito Ihe pertenceria(59).

$\mathrm{Na}$ sua estrutura interna, os ludi Capitolini compreendiam os três

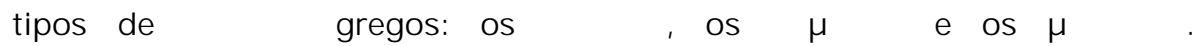
Como diz Suetónio, tratava-se de um quinquennale certamen Capitolino loui triplex, musicum, equestre, gymnicum (Dom. 4, 8), a que se apresentavam numerosíssimos concorrentes. Além das provas consagradas, o mesmo historiador dá- nos conta da existência de um concurso de eloquência latina e grega; de que, além dos citaredos, concorriam os chorocitharistae (os tocadores de cítara que acompanhavam o coro) e os psilocitharistae (citaristas que não cantavam, apenas tocavam); e, ainda, de que

(56) Para marcar a importância desse templo e do culto aí prestado, usou-se mármore precioso e nunca utilizado em outros monumentos em Roma; as portas eram chapeadas a ouro e as telhas que o cobriam eram também douradas.

(57) Simbolicamente, o próprio Vespasiano participou dos trabalhos (Suet., Vesp. 8, 9). Será a esses dois templos em honra de Júpiter, o reconstruído e o que Domiciano fez erguer de novo, que Marcial alude em VI 10, 3 (templa quidem dedit ille loui) e IX 3, 7 (pro Capitolinis quid enim tibi soluere templis).

(58) Desse poema resta um fragmento, de cuja autenticidade nem todos estão seguros, transmitido no séc. IX pelo escritor bizantino Jorge Sincelo.

(59) E, de resto, essa a versão que os poetas 'da situação' confirmam. V.por ex., em Marcial IX 101, longo epigrama que enumera os actos e benesses de Domiciano em paralelo com os feitos de Hércules, os v. I 3-6: asseruit possessa malis Palatia regnis, / prima suo gessit pro loue bella puer; / solus luleas cum iam retineret habenas, / tradidit inque suo tertius orbe fuit. 
havia uma corrida em que competiam jovens do sexo feminino(60). Neste aspecto, os ludi Capitolini retomavam o costume das cidades dóricas, já que, por exemplo, as mulheres de Esparta também participavam nas provas da corrida. De qualquer modo, sabemos que foram justamente estas provas para que Suetónio chama a atenção, talvez porque eram as mais inusitadas, aquelas que quase de imediato foram abandonadas. No caso da corrida feminina, tal desaparecimento poderá ainda ter-se devido a uma última concessão à opinião dos Romanos grauiores, aqueles que continuavam a opor o seu veto moralista aos exercícios físicos, muito mais tratando- se de mulheres(61).

O carácter grego destes jogos via-se também na forma como Domiciano a eles assistia. O princeps estava vestido à moda grega, com a clâmide púrpura e as crepidae, as sandálias gregas. Na cabeça colocava uma coroa de ouro com a representação da tríade capitolina, Júpiter, Juno e Minerva. Junto dele tomavam lugar o Flamen Dialis e os membros do collegium Flauiale que expressamente instituíra para prestar culto aos Flávios desaparecidos e deificados, Vespasiano e Tito. Todos os sacerdotes estavam vestidos como o imperador mas, na coroa que usavam, estava também representada a efígie de Domiciano, ao lado das três (outras) divindades. Eram esses sacerdotes e o princeps os juízes das provas, os que atribuíam os prémios, constituídos por coroas de folhas de carvalho, em ouro, que o próprio Domiciano entregava aos vencedoresí62). Como bem nota Brian W. Jones(63), "it was a display arranged to show the regime to the world".

A importância que Domiciano atribuía a estes jogos pode ainda verse na construção de edifícios especiais para as provas gímnicas e para as provas musicais. Para aquelas mandou construir, no Campo de Marte, um Stadium, com cerca de 250 metros de comprimento e capacidade para 15 mil espectadores, situado onde hoje fica a Piazza Navona, que Ihe conserva a forma e cujo nome deriva directamente da designação do

(60)/ n stadio (...) cursu etiam uirgines (ibidem).

(61) Sobre tal perspectiva, v.por ex. a associação que Marcial faz entre uma atleta e a sua orientação sexual: a Filénis de VII 67 é uma tribade.

(62) Marcial IV 1,6: perque manus tantas plurimas quercus eat. V. tb IV 54, 1- 2; IX 3, 8; 23 , 5; 35, 10; 101,22; Estácio, Siluae IV 2, 62; V 3, 23 I ; Juv.IV 387.

(63) The emperor Domitian. London, Routledge, 1992, p. 103. 
agon Capitolinus. Para as provas musicais, mandou erigir o Odeum, também no Campo de Marte, com capacidade para 5 mil espectadores. Ambos os recintos eram magníficos e podiam ainda admirar-se no séc. IV(64).

Sobre os ludi Capitolini existe informação relativamente abundante quanto a provas e concorrentes que será curioso evocar.

Sabemos por Quintiliano que o tema proposto para o concurso de eloquência era fixo e consistia no elogio de Júpiter Capitolino (10 3, 7, 4: laudes Capitolini louis perpetua sacri certaminis materia). Ora, urna vez que as condições políticas do principado de Domiciano se pautavam pela adulação compulsiva e servil, dado ainda que o princeps exigia que todos se lhe dirigissem tratando- o por dominus et deusi65), não podemos senão deduzir que tal tema único aproveitaria, como variação possível e inevitável, a evocação do salvamento milagroso de Domiciano na já referida noite de 69, bem como a relação especial de protecção que ligava Júpiter e o imperador. Cabe aqui dizer que foi justamente esse um dos mais frutuosos filões dos epigramas adulatórios de Marcial dirigidos ao último dos flávios. Nos Epigramas, são constantes os paralelos entre Domiciano e Júpiter, dos quais o deus do Olimpo sai quase sempre em desvantagem perante a grandeza do deus do Palatino(66). São também constantes as identificações de Domiciano com Júpiter: Marcial refere amiúde o senhor dos Romanos como Tonansi67).

Ora, uma vez que, em 96, Domiciano foi assassinado e o Senado votou a damnatio memoriae do imperador, obrigando a que o seu nome e os seus actos fossem riscados da lembrança dos homens, poderá ter sido essa a principal razão de terem desaparecido dos ludi Capitolini as provas em que especificamente se fazia a adulatio do odiado tirano, isto é, o concurso de eloquência latina e grega.

(64) V. Suet., Dom. 5, 2; Eutrópio 7. 23 e Amiano Marcelino 16. 10. 14.

(65) V. Suet., Dom. 13, 4-5; Díon 67. 4. 7, testemunho retomado e ampliado em historiadores posteriores (Aur. Vict. De Caes. 11.2; Ps. Aur. Vict. Epit 11.6; Eutrop. 7. 23; Oros. 7. 10), e de que Marcial se faz subserviente eco (V 8,1; VII 34, 8; VIII 2, 6), para logo rejeitar a adulação, morto Domiciano $(X 72,3)$.

(66) Cf. IV I; 8, 12; VI 10; VIII 15, 2; IX 3; 18; 36; 86, 8 (utrumque louem); 91; XIII 4; XIV I. Veja-se ainda que o próprio puer delicatus de Domiciano, Eárino, é comparado e identificado com Ganimedes (IX I I ; I 6; 36).

(67) Cf. VI 10, 9; VII 56, 4; 60, I - 2; 99, I; IX 39, I; 65, I; 86, 7; 101,24. 
Conhece-se um caso que confirma a hipótese de que o tema fixo destas provas se transfomava em louvor do princeps no poder e, simultaneamente, revela o carácter despótico de Domiciano. No tempo de Vespasiano, o senador Palfúrio Sura fora expulso da ordem senatorial por comportamento indigno e incompatível com a dignidade da sua condição. Sura tinha participado no ogon Neroneus e competira com uma jovem espartana na corrida(68). Ora, anos depois, Sura apresentou-se a concurso nos ludi Capitolini e ganhou o prémio de eloquência latina, ao que parece com claras intenções de agradar a Domiciano e, assim, dele conseguir a readmissão na lista dos senadores. Suetónio conta-nos que todo o povo presente no agon interveio por ele, após a conquista do prémio, pedindo ao Imperador que o readmitisse no senado. Mas Domiciano nullo responso dignatus tacere tantum modo iussit uoce praeconis (Dom. 13. 3).

A história, a poesia, a epigrafia conservaram-nos o nome de outros vencedores neste certamen Capitolinum e em diferentes sessões.

$\mathrm{Na}$ sua primeira realização, em 86, um certo Colino conquistou um prémio, ao que tudo indica, na prova de poesia latina. Marcial celebra- 0 , no epigrama IV 54, por ter sido o primeiro a receber a coroa dos ludi Capitolini (v.2: prima cingere fronde), mas, como era costume fazer aos que triunfavam e gozavam da glória e do favor das multidões, logo lhe lembra que a vida é efémera e que a fama se esvai, rápida(69).

Na sessão seguinte, em 90, contava- se entre os participantes Lúcio Anio Floro e é ele próprio quem diz que recebeu aplauso unânime do público, que o queria ver vencedor, mas que o imperador lhe negou a vitória, não porque tivesse sido movido por sentimentos de inveja, vendo-o tão jovem, mas por não querer que um concorrente vindo da Africa ganhasse a corona magni louis ${ }^{70}$ ).

No certamen de 94 sabemos que houve 52 concorrentes para a poesia grega, o que demonstra bem a popularidade dos jogos. Tal dado é- nos fornecido pela lápide sepulcral de um desses participantes, Quinto

${ }^{(68)}$ Schol. ad luu. IV 53: sub Nerone luctatus est cum uirgine Lacedaemonia in agone.

(69) V. v. I - 2; si sapis, utaris totis, Colline, diebus / extremumque tibi semper adesse putes.

(70) Floro, p.221 Malcovati: inuito quidem Caesare, non quod tibi puero inuideret, sed ne Africa coronam magni louis attingeret. 
Sulpicio Máximo, morto com I I anos, 5 meses e 12 dias, ao que parece consumido justamente pelo excesso de estudo. O epitáfio (C/L VI 33976 = ILS 5177) é dedicado pelos pais do jovem, que revelam o tema da prova (a censura de Júpiter a Hélio por ter dado o carro a Faetonte), dizem que o filho cum honore discessit e, de seguida e como suprema homenagem, transcrevem os 43 hexametros que o jovem apresentou a concurso.

Cabe aqui notar, como fez Italo Lana( $\left.{ }^{71}\right)$, que Sulpicio Máximo era um poeta muito jovem e que, sem dúvida, tal corresponde a uma divisão dos concorrentes por estratos etários, que se verificaria nas provas musicais, tal como nas atléticas. Além disso, o tema proposto aproxima-se demasiado daqueles que eram tratados nas escolas de retórica, o que leva o citado estudioso a avançar a hipótese de que a estes concursos se apresentassem os 'melhores da classe', o que serviria como claro incentivo para os jovens alunos.

Marcial fala também de um certo Diodoro que viera de Alexandria para participar nos ludi de Domiciano, ao que parece nesta mesma sessão de 94, já que o epigrama (40) em que se lhe refere pertence ao Livro IX, publicado em 95. Vindo de onde vinha, Diodoro deve ter-se apresentado a concurso na prova de poesia grega. Nada mais sabemos, todavia, sobre ele: com certeza, não se sagrou vencedor, já que Marcial não o saúda por isso mas sim por um estranho voto que sua mulher fizera pelo regresso rápido, e em segurança, do marido.

Talvez também em 94, o poeta Estácio sofreu um duro revés de que jamais se recompôs e o levou até a retirar-se para a Campânia, tendose- Ihe tornado insuportável a vida em Roma. O que aconteceu foi que, sendo ele já um poeta de méritos reconhecidos, que se sagrara vencedor em poesia nos ludi de Nápoles e recebera por três vezes a coroa de folhas de oliveira nos ludi Albani, foi derrotado no agon

(7l) "I ludi Capitolini di Domiziano": Rivista di Filologia e di Istruzione Classica 29 (1951) 145- 160.

(72) Cf. Silu. III 5, 28 ss; V 3, 228 ss.; Juv.VII 82- 7. Uma das vitórias nos ludi Albani conquistara-a com um poema que celebrava as guerras da Germania e a vitoriosa actuação de Domiciano contra os Dacos. 
Na sessão de 90 ou na de 94, o poeta trágico Scaeuus Memor ganhou a prova de poesia latina( ${ }^{73}>$. Marcial celebra-o em XI 9, num dístico que parece destinado a servir de epígrafe a uma representação pictórica do homenageadoí ${ }^{74}$ ) e recorda- o em XI 10, epigrama de louvor ao irmão de Mémore, Turno, poeta satírico dos mais queridos no momento. Do valor de Cevo Mémore é impossível fazer juízo, uma vez que dele possuímos não mais que dois fragmentos e apenas um deles não oferece dúvidas quanto à autoria. Parece no entanto adivinhar-se que se dedicava à tragédia de assunto mitológico(75), como convinha a quem queria estar bem e a salvo nos tempos incertos que corriamí ${ }^{76}$ ).

Uma outra inscrição (CIL IX 2860 = ILS 5178) conserva-nos o nome do vencedor em poesia latina, no concurso de 106: Lúcio Valério Pudente, natural de Histónio, que coronatus est inter poetas Latinos omnibus sententiis iudicum. Por tal feito, a sua cidade natal statuam aere collato decreuit. Ora, também este vencedor era um adolescente, que não contava mais de 13 anos. $\mathrm{Na}$ idade adulta tornou-se funcionário público ( curator rei publicae Aeserninorum datus ab Imperatore) e, manifestamente, abandonou as Musas. O que poderá abonar a hipótese, acima exposta, de Italo Lana. Também este jovem competiria no escalão dos Ttcâôeç.

(73) Italo Lana, art. cit. p. I 56, pensa que ele teria sido vencedor numa prova específica de poesia dramática, que se distinguiria do de poesia latina. Para a hipótese de autonomia deste tipo de prova, chama o exemplo já citado da comédia grega de Germânico que Cláudio fez apresentar, nos jogos de Nápoles, em memória do irmão, e que venceu o certame.

(74) H. Bardon (La littérature latine inconnue II. L' époque impériale. Paris, Klincksieck, 1956, p.216) crê que se tratava de uma estátua, hipótese retomada em OCD s.u. 'Memor', e refutada por Luc Duret ("Dans $\Gamma$ ombre des plus grands: II. Poètes et prosateurs mal connus de la latinité d'argent" in ANRWII 32.5, 1986, p.3212 n. 336).

(75) O primeiro fragmento, transmitido pelo gramático Sérgio (GLK 4, 537, 17-18) é, com toda a certeza, um passo do coro de cativas troianas que se dirigem, lamentosas, a Hécuba. O segundo (Fulgêncio, Serm. ant. 25), de autenticidade duvidosa, pertenceria a uma tragédia sobre Hércules.

(76) De resto, a acreditar nos escoliastas de Juvenal, o irmão de Mémore, Turno, gozava do favor de Domiciano, como acontecera sob Tito (schol. ad luu. I 20: Turnus hic libertini generis ad honores ambitione prouectus est potens in aula Vespasianorum Titi et Domitiani). Tai circunstância, aliada ao que pode deduzir-se sobre a obra satírica de Turno, a partir dos fragmentos até nós chegados (ocupar-se-ia de enegrecer e condenar a época de Nero), aponta para uma situação de claro 'enfileiramento' político dos dois irmãos, apoiantes empenhados de Domiciano. 
Quanto às provas atléticas, tal divisão por estratos etários parece não oferecer qualquer dúvida, e as inscrições que referem participantes nestes ludi apontam claramente nesse sentido. Observemos o percurso de Tito Flávio Arquíbio, natural de Alexandria(77). Ganhou, entre os Ttcuõeç, o pancrácio, nos Actia de Antioquia. Em 90, nos mesmos jogos, em Alexandria, ganhou também o pancrácio, mas desta vez já entre os

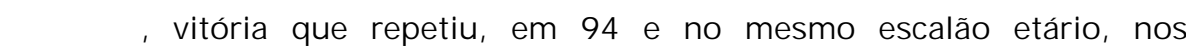
ludi Capitolini. Depois, em feito nunca antes conseguido por nenhum atleta, venceu também o pancrácio, no agon Capitolinus, por três vezes consecutivas (em 98, 102 e 106), concorrendo já entre os avópes. Trata-se, ao que tudo indica, de um atleta profissional, cuja única ocupação seria a de treinar-se para competir (e vencer) em todas as provas possíveis, em especial as de maior nomeada(78).

Da informação, até nós chegada, sobre os atletas que participavam nos certamina graeca, podemos, de resto, concluir que eram, na sua grande maioria, se não na totalidade, profissionais que percorriam todos os jogos do novo ciclo constituído pelo agon Capitolinus, que devia realizar-se em Julho, depois pelos Sebastà de Nápoles, em Agosto, e finalmente pelos Actia, em Nicópolis, no mês de Setembro.

Marcial (VI 77, 3) conservou-nos ainda a memória de Tito Flávio Artemidoro, natural da Síria e vencedor do pancrácio, em 86 (C/G 3426). Mas, curiosamente, no epigrama de Marcial, Artemidoro é tomado tãosó como exemplo de força.

Desta múltipla informação, que aponta para uma grande quantidade de participantes, vindos dos mais variados pontos do império, parece ser possível tirarmos a conclusão de que o agon Capitolinus se tornou a prova mais apetecida por atletas, aurigas e artistas, particularmente os poetas. Sem ser necessário retomar o caso de Estácio e a sua decepção por ter sido derrotado nesse certamen, pois naturalmente se sentiu 148 ferido no seu orgulho de poeta laureado, podemos encontrar eco de tal interesse generalizado na obra de Marcial e Juvenal. Em Sat VI 387, sabemos que um certo Polião ansiava pela coroa de folhas de carvalho,

(77) Kaibel, / . G. / . 747, 1.12 (citado por Italo Lana, art. cil p. 152).

(78) Em C/ G 3674, conserva- se ainda a memória de Marco Aurélio Coro, de Cízico, que venceu o pancrácio dos jovens, em 116. 
Capitolina quercus, como lirista. Em Marcial IX 23, conhecemos Caro, vencedor nos jogos Albanos, que se prepara para concorrer aos jogos Capitolinos, onde deseja e espera também ganhar. Será curioso verificar, neste epigrama, que para todos os efeitos equivale a um epinicio, a diferença de perspectiva em relação à forma como eram louvados e glorificados os atletas e vencedores dos jogos na Grécia. Marcial interroga Caro, querendo saber o que ele fez à coroa conquistada nos ludi Albani, e reproduz a resposta do vencedor: a própria corona foi cingir a cabeça de Domiciano, num busto, em mármore, que Caro possuía e que muito venerava. Ou seja: a maior recompensa do vencedor é partilhar a migaIha de glória de ser coroado pelo princeps, mas a verdadeira vitória pertence ao imperador. A maior ambição de todos é, afinal, e na perspectiva de adulatio política aqui manifestada, prestar culto ao deus vivo que Domiciano é. Bem longe estamos do íßpovíkns aclamado como herói na sua cidade e que oferecia a Zeus a coroa conquistada nos jogos Olímpicos. Nestes ludi e nesta época, os vencedores pertencem necessariamente à faixa de apoiantes do imperador, são os que cantam o poder instituído e os que lhe oferecem a vitória em preito de subserviente homenagem.

O sucesso dos ludi Capitolini foi, todavia, tanto que nem a damnatio memoriae do seu fundador Ihes pós termo(79). Realizaram-se, ao que tudo indica, até ao séc. IV e só tiveram fim quando todos os jogos foram banidos por Honório. Tal parece dever-se ao carácter universalista que Domiciano Ihes quis imprimir, fazendo de Roma também o centro das manifestações superiores da cultura do espírito e do corpo, intenção bem diferente, apesar de todos os objectivos adulatórios e de propaganda, da finalidade de promoção pessoal e glorificação do seu génio que Nero claramente atribuía aos Neronia.

Outros imperadores realizaram, nos séculos seguintes, certamina graeca, como foi o caso, por exemplo, de Antonino Pio, que instituiu os Eusebia, em Putéolos, em memória de Adriano(80), de Marco Aurélio que, para celebrar a vitória que, juntamente com Cómodo, obtivera sobre os

(79) Os ludi Albani, ao invés, devem ter sido suprimidos após o assassínio de Domiciano, pois cessou toda a informação sobre eles.

(89) SHA, Hadr. 27. 
Partos, celebrou uns Epinikia em 176, de Alexandre Severo, que deu jogos triunfais nos quais participaram atletas e artistas de todas as partes do império, ou de Aureliano que, em 274, instituiu um agon Solis, relacionado com o culto do Sol. Outros, como já vimos que foi o caso de Gordiano relativamente aos Neronia, recuperaram ludi caídos em desuso. A perspectiva pela qual eram vistos os que participavam em tais tipos de espectáculos, porém, nunca mudou por completo: sempre foi considerado uma desonra, uma infâmia, uma ignomínia, a exibição dos membros das classes dominantes no teatro, no anfiteatro ou no circo, como fizeram Nero, o histrião, Cómodo, o gladiador, Caracala, o auriga. Não será mesmo exagero dizer que foram tais infracções à ordem moral que definitivamente perderam tais principes aos olhos e no apoio dos que tinham poder e influência. Além disso, a informação que chegou até nós vem sempre transmitida através da pena de escritores que manifestamente saíram das fileiras dessas classes dominantes e conservadoras, o que à partida determina os juízos de valor que emitem. Ainda assim, é fácil perceber no que dizem que os certamina graeca ganharam a adesão incondicional do povo, que os exigia e apreciava em pé de igualdade com os outros espectáculos em que consumiam o tempo e gastavam a vida. E essa parece-nos ser, afinal, a grande diferença entre os jogos da Grécia e os de Roma: não há nestes nenhum espírito de unidade nacional, nenhuma exaltação de valores, nenhum ideal de ultrapassar as limitações do que é humano. $E$ certo que, quando os Romanos deixaram que os certamina graeca se institucionalizassem no seu mundo, já há muito, na Grécia, se desvanecera esse espírito, substituindo-se os atletas pelos profissionais, empenhados apenas nas recompensas e na vitória, conseguida quantas vezes com actos pouco limpos relativamente aos adversários. Como bem notou H.-I. Marrou, talvez a persistente desconfiança das classes mais esclarecidas intelectualmente, e a não 150 aceitação plena nem dos certamina graeca nem do puro exercício físico no programa de educação do jovem romano se tenham devido a que "leur prestige rémanent était déjà trop affaibli dans leur patrie d'origine pour pouvoir s'imposer à l'imitation des Latins"(81).

(8|) Henri- Irénée Marrou, Histoire de l'éducation dans l'Antiquité. 2. Le monde romain. Paris, Seuil, p.39. 
Em Roma, pois, trata-se de espectáculo e apenas de espectáculo. Grandioso, frequente e profundamente ligado aos meandros da propaganda política de quem o proporcionava. Muitas vezes com resultados falseados e prémios atribuídos por razões bem distantes do mérito. Nada mais que isso. Com esse aparato se contentavam os que a ele assistiam. E com a breve glória das palmas se enchiam de orgulho os que nele participavam. 